angiography one can predict not only the localization of lesions, but also their pathology. This is often true, but by no means aiways so. One has seen gliomas giving appearances indistinguishable from meningiomas, and other malignant gliomas failing to reveal pathological vessels at any stage from early arteriography to late plebography. Attractive though it may be to hope that the radiograph will substitute for the microscope in the pathological diagnosis of many brain tumours, that stage has been reached in only a minority of cases. None the less no one interested in neurology can afford to disregard the very useful information provided by angiography, which has become an essential diagnostic tool, in large measure thanks to the author of the book. It is to be strongly recommended.

J.W.D.B.

\section{SURGERY OF CATARACT}

By Daniel B. KIRby, A.M., M.D., LL.D. Pp. xx + 695, with 339 illustrations, 21 in colour. London and New York: J. B. Lippincott. 1950. fi2.

It may seem strange to an outsider that a book of nearly 700 pages can be written about one operation which frequently takes less than 15 minutes to perform, but it must be remembered that the cataract operation occupies a very special place in the life and heart of the ophthalmic surgeon, often being the yardstick by which his competence is measured.

Albeit, this is a monumental work, touching on a wide variety of subjects concerned, some of them rather remotely, with cataract surgery. History, anatomy, physiology, the training of a cataract surgeon and his approach not only to his patient but even to his Maker are not neglected. There is a good deal of rather fulsome repetition in this part of the book, which might have been more severely edited.

The main emphasis is naturally on the intracapsular operation, to which Dr. Kirby has made important contributions, and this, the largest section of the book, is very well done and fascinating to read. Dr. Kirby reviews the work of other surgeons, usually in their own words, by means of long extracts from their writings, and then explains his own conclusions not in the form of a rigid 'method,' but in an elastic 'system' by which he can adapt himself to the varying conditions found both before and during the operation. He believes that the cataract surgeon should have at his command a large variety of manoeuvres and should be able to choose, use and alter them at will. $\mathrm{He}$ is thus no bigot and has obviously been receptive of new ideas during 30 years of operating experience. He frequently puts forward his own innovations, particularly his cylindrical-handled instruments, not suggesting that all surgeons should adopt them but that they should try them if their own technique is not yielding the results that they expect.

The book is admirably produced and the coloured illustrations are excellent. Inevitably no one of his readers will agree with all that Dr. Kirby says, but this, so far from being a drawback, will stimulate them to re-examine their own technique and see what can be learnt from this very lively mind. Many may without loss take father's advice for reading Scott's novels and skip the first few chapters.

\section{WHEELER AND JACK'S HANDBOOK OF MEDICINE}

Revised by Robert CoOpe, M.D., B.Sc., F.R.C.P. I Ith Edition. Pp. xvi +648 , with 62 illustrations. Edinburgh: E. \& S. Livingstone. $195^{\circ}$. 20 .

The student who holds that it is inadvisable to see patients for a period of three months preceding the final examination, on the grounds that they tend to confuse the clear picture of disease required for this hurdle, would do well to digest the fureword to this handbook. 'Our art is not to be learned save by its exercise and use,' and this book, of a size to be admitted into a capacious pocket, is an ideal practical companion for the period of clinical clerking.

\section{THE BRITISH ENCYCLOPAEDIA OF MEDICAL PRACTICE (Vol. 2)}

Edited by The RT. HoN. LORD HORDER, G.C.V.O., M.D., F.R.C.P. and Edition. Pp. xiii + 755, with 115 illustrations. London: Butterworth and Co. 1950. f3.

The high standard of the first volume has been maintained in the present work, which has been expanded by the introduction of two new chapters on atomic energy and blast injuries. These new sections, excellently written by Dr. J. F. Loutit and Sir Cecil Wakeley respectively, together with the greatly expanded chapter on aviation medicine by Sir Harold Whittingham, are not only an index of the perilous times in which we live, but also a sharp reminder of the increasingly important part that doctors would be expected to play in any future war. All three chapters, therefore, will repay close study.

New contributors will be welcomed amongst the authors of the first edition. In this regard, Dr. W. Tegner's excellent accounts of ankylosing spondylitis and backache should be mentioned. The section on ascites has been rewritten with advantage by Dr. G. E. Beaumont, who recognizes the fact that some doctors may have had a classical education, and, perhaps, have not forgotten all their Greek. Mr. V. Zachary Cope, our doyen amongst 
the experts on the acute abdomen, has given a masterly account on appendicitis - the commonest of all abdominal emergencies.

These scattered remarks should be regarded as an indication of the reviewer's most favourable impressions, rather than as an invidious distinction between varying degrees of excellence of important contributions. He must, however, express some disappointment with the chapter on rheumatoid arthritis. If it had been written by a lesser authority than Dr. W. S. C. Copeman it might, perhaps, have been satisfying.

D.S.L.

\section{STEROID HORMONES AND TUMOURS}

By Alexander Lipschutz, M.D. Pp. xi +309 , with I I I illustrations. London: Baillière, Tindall $\&$ Cox. Baltimore: The Williams and Wilkins Co. I950. $£^{2} 6 \mathrm{~s} .6 \mathrm{~d}$.

This book, although apparently designed for a wider public, will be of interest only to laboratory research workers in the comparatively narrow field which it covers. It consists largely of an account of experiments performed by the author and his associates over a period of some 15 years. The experiments comprised the production of abdominal fibromyomata in guinea-pigs by oestrogens, naturally occurring and synthetic, and the inhibition of this action by progesterone, androgens and adrenocortical steroids. Much allied literature is referred to but, for the most part, is not discussed in a critical fashion. There are about 800 references which should be of assistance to the research worker.

Where the author applies himself to describing his own experimental work he can be understood, but when discussing the wider significance of results and developing arguments in the sphere of speculation he frequently fails to make his meaning clear. This alone makes the book difficult to read and, in addition, there are numerous typographical errors, some of the tables are not clear, some figure legends are confusing or are divorced from the figures to which they refer, and at least one has neither legend nor text reference. One important error of fact was noticed by the reviewer on p. II 3 ; the author states that 'One will remember the work of McIntosh who reported in 1933 production of filtrable tumours by the administration of tar to rats, and later on also in fowls (McIntosh and Selbie, I939).' To the reviewer's knowledge no one has ever claimed to produce filtrable tumours in rats with chemical carcinogens and quite certainly the cited author did not.

Those who read this book should approach it critically.

\section{METHODS OF TISSUE CULTURE}

By RAYMond C. PARKer, Ph.D. 2nd Edition (revised). Pp. xxiv +294 , with I 3 illustrations $\varrho$ London: Cassell and Co. 1950. 57s. 6d.

The first edition of this book described exactly the tissue culture practice of Alexis Carrel, one of the author's teachers and one of the most eminentand authoritative workers responsible for the first great strides in this branch of study. This second? edition has appeared 12 years after the first and $\mathbb{Q}$ the author, with the advantage of mature judgmentw and long experience, is obviously master of his? subject. Also the author's exposition is good and? the book is well written in simple language and is a $\vec{a}$ pleasure to read.

Many laboratory workers, even if not engaged in tissue culture, should read this book, for tissue culture has a wide variety of applications which in clude the study of antibody formation, bacterial in fection, hormonal action, nutrient requirements of $\omega$ living cells, cancer research, blood diseases, embryology and organ growth, cell metabolism, thein action of drugs upon cells, the growth and attenuation of viruses for vaccines and other purposes, the ${ }^{\frac{1}{\sigma}}$ preparation of specimens for the electron microscope음 and the diagnosis of doubtful tumours.

The book begins with an historical introduction 3 which immediately captures the reader's interest Subsequent chapters deal with laboratory design, cleaning and sterilization, and the preparation $8 f$ fo media (this includes an excellent chapter by J. Morgan on the 'Development of Synthetic Medis) in great, but interesting, detail reminiscent of thes ritual demanded by Carrel in his laboratories. However, such detailed description is no disadvantage, for it leads to clarity and comprehensive- $\frac{O}{D}$ ness. The chapters which follow are concerned $\varrho$ with the different types of tissue cultures, illustrated $\overrightarrow{\vec{O}}$ and made interesting by relevant experimental 3 findings. Finally, methods of study of tissue cultures? are described; growth measurements by simpleo mensuration and by metabolic and biochemical studies; histological procedures, which have to be 3 . modified for tissue culture and lastly photomicro-igraphy and microcinematography. There are 3 . numerous illustrations all of which are excellent; the bibliography is adequate, well selected, and does 3 not reach those excesses which usually result from attempts to be uncritically comprehensive.

There are but few adverse criticisms which could $\triangle$ be made and these are of no importance in view of the fact that this book achieves its object so successfully, save one. However, Chapter IV on cleansingo and sterilization seems to be largely unnecessary. $N$ It could be shortened with profit as most of such in-N formation can be found in standard texts on bac- $\omega$ teriological technique. In addition the author does< not appear to be so much at ease when discussing the first principles of sterilization as he is elsewhere in his otherwise excellent book. 